\title{
Enlargement of apartments in socialist housing estates in Skopje under transition: The tension between individual preferences and collective action
}

\author{
Jasna Mariotti ${ }^{1}$ (D) $\cdot$ Daniel Baldwin Hess ${ }^{2}$ D
}

Received: 23 April 2020 / Accepted: 11 June 2021

(C) The Author(s) 2021

\begin{abstract}
The post-socialist urban restructuring of Skopje, North Macedonia has been characterized by significant changes in the built fabric of the city, resulting from the political, economic and societal processes following the dissolution of Yugoslavia. In early 1990s and postprivatization, there was a dynamic transformation of the city's housing stock in post-WWII prefabricated apartment buildings. Flat owners in socialist-era housing estates in Skopje modified their apartments by expanding and enclosing balconies, thus gaining more living space. Garages were converted into shops and ground-floor and first-floor apartments were renovated into offices, resulting in commercialization of previous residential space. To better understand the spatial disorder triggered by transformation of housing estates during the lengthy transition from a centrally-planned system to a market economy, this article evaluates various spontaneous and planned practices of transformation of residential space in housing estates in post-socialist Skopje. We analyze these changing practices of transformation through fieldwork and focus group discussions with residents. We also review archival material and administrative and legal documents, including municipal master plans and national planning laws and decisions related to housing estates in post1991 Skopje. Findings emphasize the complex interplay between many actors, ideologies and interests that shape the experience of urban life in post-socialist Skopje, evidenced by outcomes related to housing choice and renovation practice, especially the enclosure of balconies for providing more living space. Such interventions are viewed as important steps towards improving living conditions in prefabricated apartment buildings in Skopje. Individual decisions about apartment renovation affect urban planning at the neighborhood level, and the findings from this research thus inform residential mobility and neighborhood-level strategic decision making. The aim is to help neighborhoods-built in an earlier socio-political era under a central planning system — to adapt to future demands.
\end{abstract}

Apartments · Balcony · Enlargement · Housing estates · Post-privatization Skopje · Transition

Jasna Mariotti

j.mariotti@qub.ac.uk

1 School of Natural and Built Environment, Queen's University Belfast, Belfast, UK

2 School of Architecture and Planning, University at Buffalo, State University of New York, Buffalo, NY, USA 


\section{Introduction}

The transformation of cities in Central and Eastern Europe (CEE) during recent decades has been a focus of research among scholars, resulting from the political, economic and societal processes of change in the past 30 years (Hamilton et al., 2005; Stanilov, 2007). These studies focus on the socio-spatial patterns of transformation (Nae \& Turnock, 2011; Sykora, 1999; Tosics, 2007), large-scale commercial development in capital cities (Kreja, 2007; Mariotti \& Koželj, 2016) and patterns of migration and suburbanization (Krisjane \& Berzins, 2012; Leetmaa \& Tammaru, 2007). Studies about residential mobility in former socialist countries focus on ethnicity, population groups and their socio-economic status (Hess et al., 2018; Kährik \& Tammaru, 2010; Kulu \& Billari, 2004) and also housing choices and adjustments as significant non-market options (Mandič, 2001). Furthermore, studies engaging political shifts and turbulence (Puur et al., 2019) and their impact on socio-economic change (Tammaru et al., 2016) offer insights into the dynamics of the transformative processes of cities after the fall of state socialism in countries in CEE.

Centrally-planned housing estates dating from the period of state socialism were often built from prefabricated panels; in order to reduce costs, design and construction methods were standardized, with predetermined sizes of housing blocks based on the performance and capacity of production facilities (Meuser \& Zadorin, 2016). These spatial constructs dominated the post-WWII cityscapes in CEE (Hess et al., 2018).

Urban planning during this period primarily addressed the rigid disposition of housing slabs and their relationship to surrounding greenery (Metspalu \& Hess, 2018), and architecture was seen as an instrument of social reform (Kulić, 2012). These relationships were displayed in the domestic landscapes created during this period, when designs followed the principles of modernism and functionalism (Hess \& Tammaru, 2019a, b).

The aim of this article is to explore dimensions of housing occupancy and tenurespecifically individual decisions to renovate and/or expand individual apartments, or move to a new housing opportunity. We link these actions-relocation, or apartment renovation or expansion-and related outcomes to urban planning practice after 1991. We contribute to scholarly literature on housing dynamics by exploring changing housing conditions in post-WWII apartment buildings in countries still undergoing transition and in which the unified policies of the European Union (EU) are not fully implemented. When commercial housing markets were introduced in CEE and after the fall of socialism, it became possible for people to exercise choice in their accommodations; some sought larger living space to increase their daily comfort. We therefore pose the following research question: how did people make the decision to invest in enlarging their individual apartment or move to a new apartment? To answering this question, we choose North Macedonia as our study site, since it is a complex context for studying these complex processes of transformation after the fall of socialism.

North Macedonia, a member state of former Yugoslavia, experienced structural and economic changes resulting in a rise in unemployment and negative socio-economic conditions and instability following the dissolution of Yugoslavia in 1991. A lack of legislative and institutional frameworks after the fall of state socialism in former Yugoslavia impacted its housing market, paving the way for illegal construction and transformation of socialist-era housing estates in cities where master plans were outdated. Socio-political changes produced regional inequalities and disparities among all of the former member states of Yugoslavia (Bosnia and Herzegovina, Croatia, Montenegro, North Macedonia, Serbia, and Slovenia); at present, these former member states are in various phases of EU accession. 


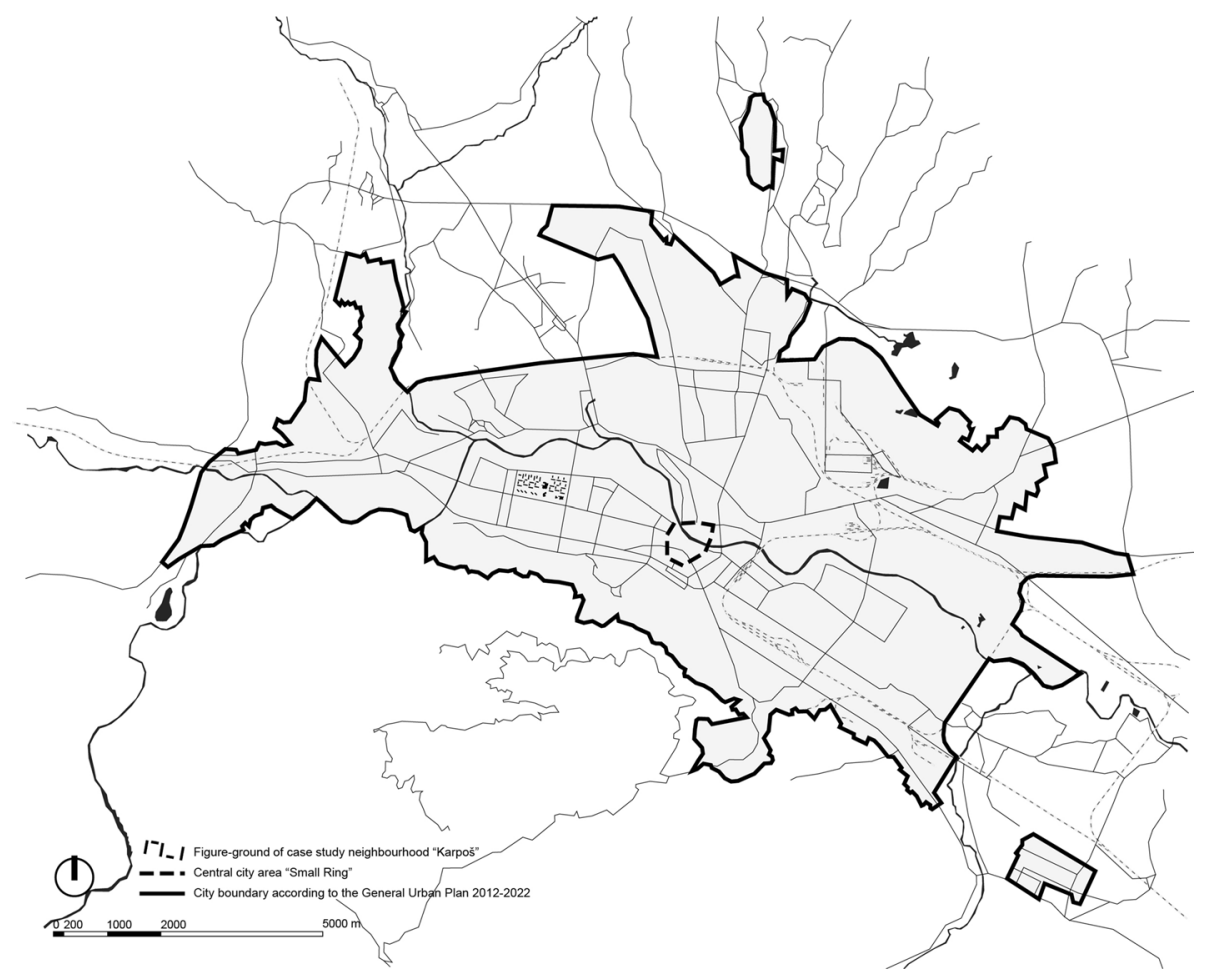

Fig. 1 The city of Skopje and the location of the case study neighborhood Karpoš Source: Created by authors

North Macedonia acquired its EU candidate status in 2005, and the delayed start of membership talks (15 years) is directly linked to a shortage of unified policies, resources and directives required of EU member states. On 26 March 2020, the long-awaited accession talks towards a membership to join the EU were officially approved for North Macedonia, with the exact date unknown of the commencement of the formal talks. The next phase of North Macedonia's governance and potential EU membership is likely to have impact on the reforms, policies and access to funding in the country in the coming years.

Recognizing an absence of rich literature in English about North Macedonia and the complex restructuring processes there since 1991, we initiate this research. By choosing the North Macedonian capital city Skopje as our site, we seek a better understanding of the impacts of the lengthy transition on the spatial and social processes of change in housing estates in the city built during state socialism. This research, therefore, explores how planning practice since 1991 supports neighborhood-scale transformative processes, focusing on enlargement of apartments and expansion of balconies and the individual decisions and preferences in this process in post-WWII housing estates.

The case study neighborhood, Karpoš, built in the late 1960s and early 1970s in the Western part of Skopje, North Macedonia (Fig. 1), is less than $4 \mathrm{~km}$ from the Skopje city center and had 5,488 inhabitants in 2008 (living in 1,568 apartments). Karpoš bears similarities with neighborhoods in other cities built during the same period where equality, access to amenities, and standardized units built with prefabricated panels were key 
features of the socialist urban form (Hess \& Metspalu, 2019). These similarities to other housing estates built in the same period across CEE make Karpoš and Skopje a compelling case study for investigating the impact of neighborhood-level transformative processes since 1991.

We perform this study by employing fieldwork observation, review of administrative and legal documents (including municipal masterplans and national laws and decisions); in addition, we conduct focus groups with neighborhood residents and an expert interview with the architect of prefabricated apartment buildings in Karpoš. The four focus groups conducted in 2019 and 2020 in Karpoš involved 24 residents who live in or own apartments in the neighborhood. Focus group discussions were confidential and anonymous. The focus groups provided an understanding of individual decisions concerning balcony expansion, residents' involvement in it, and considerations about relocation elsewhere in the city if such changes were not possible. Participants were approached on-site and asked to participate; $60 \%$ were male and $60 \%$ were age 60 or more years. An in-depth first-hand interview with Ilija Karčicki, the architect of the apartment buildings in Karpoš, allows us to clarify views of the role of local architects in the development of prefabricated technologies in housing estates in post-1963 Skopje and to better understand transformations in the neighborhood since 1991 .

We conduct this inquiry in Karpoš at two levels, first for individuals and their individual decisions related to housing in the neighborhood, and second for municipalities and urban planning policies that enabled the transformation of housing estates through planning mechanisms. These combined methods provide a foundation for understanding complex transformations in housing estates and the context in which enlargement of apartments was operationalized in Skopje after 1991.

This article is organized as follows. First, we explore the post-WWII architectural practice and development of prefabrication technology as part of housing production during the period of socialism in Skopje. Second, we explore, in the context of post-socialist urban transformation processes, the legal framework and mechanisms for the expansion of balconies within prefabricated housing estates and their effects on neighborhood transformation. Third, we investigate the everyday life decisions that guide these developments. We do so by staging focus group discussions with residents and apartment owners in Karpoš, and the results illuminate the residents' views of the transformative processes in the neighborhood since 1991 .

\section{Renovation and Self-Built Expansion of Apartments in Large Housing Estates in CEE}

Understanding renovations and self-built expansions in individual dwellings in large housing estates in CEE and the various dimensions of these transformative processes after the fall of socialism remain unexplored. Yet, the renewal, management, and maintenance of large housing estates remains one of the critical themes in scholarship addressing the newly privatized housing stock in former socialist countries (Hegedus \& Tosics, 1996). Recently, the European Commission has allocated funding to improve housing conditions in its member states (Cirman et al., 2013). Accordingly, research about the transformation of housing estates has mainly focused on EU countries and their specific institutional and socio-economic contexts (Andrews \& Sendi, 2001; Cirman et al., 2013; Gorczyca, 2016). 
Many of the countries in CEE that are not part of the unified policies of the EU are still experiencing the lengthy process of transition. Political instability, corruption, and a decline in living standards are often widespread in these countries and lead to social inequities. Access to EU funds (after these countries commence EU accession talks) is likely to have a great impact on their socio-economic developments.

Housing shortages in CEE in the early 1990s caused residents to modify and enlarge dwelling units, mostly in illegal ways. In fact, illegal construction practices and self-built extensions and adaptations have dominated the transformation of housing estates in these countries in the last 20 years. A lack of masterplans and coordinated planning together with the neoliberal approaches towards early 1990s development-often seen as the only option for apartment owners to gain more living space-facilitated the process. Furthermore, large prefabricated apartment buildings and modular housing units in CEE cities proved to be structurally viable to accommodate expansions and enclosures of balconies and subsequent enlargement of apartments. They include "kamikaze loggias" or self-built extensions of balconies in socialist-era apartment buildings in Tbilisi (Salukvadze \& Golubchikov, 2016; Wainwright, 2018) and "brovary balconies" in Ukraine where exterior porches were enclosed using vehicle parts (Blazhan, 2020). Similar illegal balcony extensions are also observed in Belgrade (Petrović, 2001). Illegal construction on public property and additions to apartments occurs in Tirana (Pojani, 2010), and balcony enclosures are common in Skopje (Bouzarovski et al., 2011). These interventions are also seen as resiliency strategies for everyday life in CEE cities, often with positive macroeconomic effects that affect residential mobility (Mandič, 2001; Cirman et al., 2013; Kuusk \& Kurnitski, 2019). The practices of housing renovation and enlargement of apartments highlight the need for more space as a main concern of residents across developing countries and countries with less developed housing markets (Seek, 1983; Tipple, 2000). In developing countries, such housing transformations are often performed without reference to urban planning concerns or in areas where planning mechanisms do not apply (Tipple, 2000).

The relationship between planning, or lack thereof, and apartment owners' input about the expansions and adaptations of individual apartments remain unexplored in countriessuch as North Macedonia - on the verge of accession to the EU. Understanding these relationships entails an in-depth look into these processes both before 1991 and after.

\section{Prefabrication and Domestic Space in Skopje Before 1991}

Centralized provision of neighborhood amenities was a critical aspect of socialism, and the allocation of housing to occupants was intended to establish an egalitarian society (Leetmaa \& Hess, 2019). To cope with rapid urbanization and industrialization in Skopje, prefabrication appeared to be an ideal solution to rapidly and economically accommodate large numbers of occupants. Although prefabrication in Skopje began almost immediately after WWII, a factory for large-scale prefabricated panel buildings was gifted by the USSR to the people of Skopje following the 1963 earthquake. Authorities in Skopje received complete documentation for the technology and operation of the prefabricated building components factory along with Soviet specialists who visited the city, helped set up the factory, and provided expertise in training local professionals. The collaboration between Macedonian and Soviet engineers was vital to the housing construction project after 1963. 


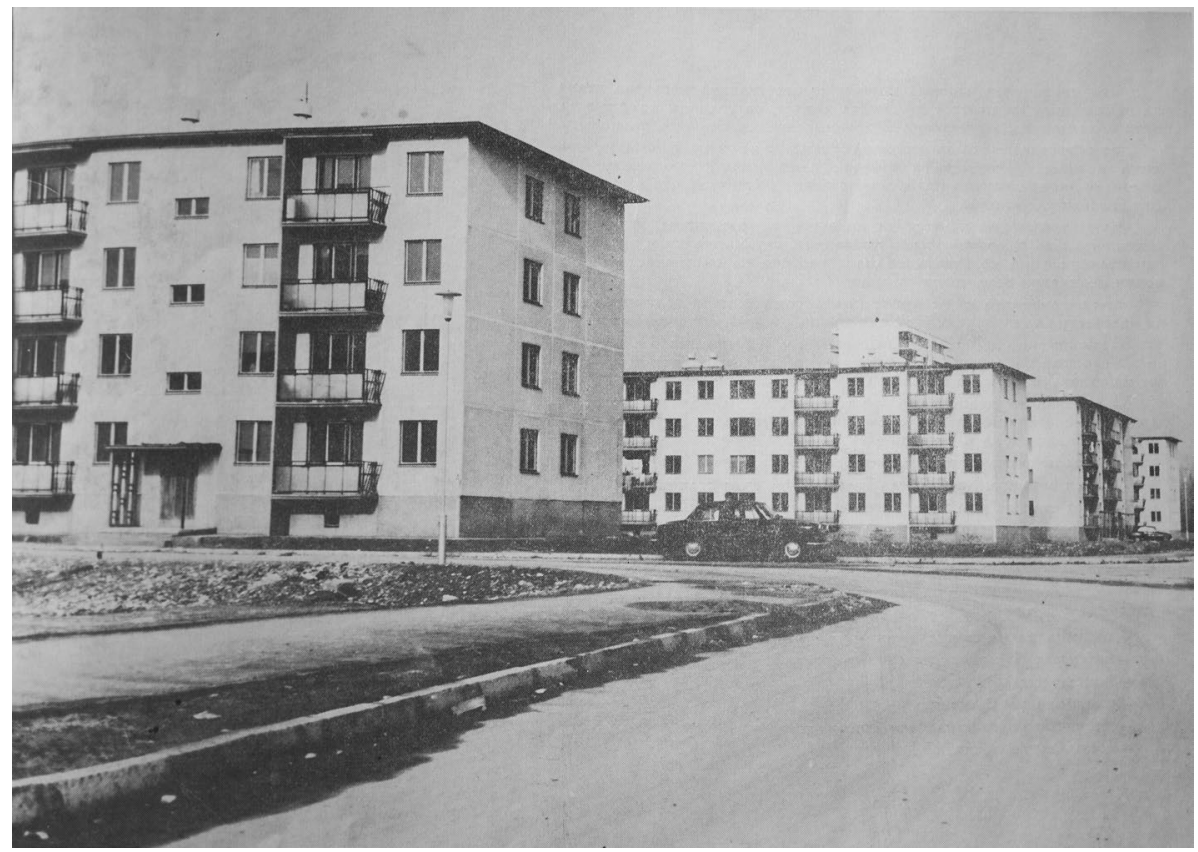

Fig. 2 Apartment buildings in Karpoš, shortly after completion Source: Institute for housing-communal management - Skopje, 1968, used with permission

Ilija Karčicki, the architect of apartment buildings in Karpoš, reflected on these intellectual exchanges:

"Together with six Soviet engineers, I was involved at first in supervision in the factory for prefabricated building components and later in redrawing of the Soviet projects and their adaptation into Macedonian standards. While developing the projects for the apartments, our attention was focused mostly on the necessary installations within each apartment, the ventilation and the materialization of the joints between the prefabricated components. The Soviet engineers were checking our projects and suggested ideas for future development. In the early days they were also overseeing the construction of the prefabricated elements and their assembly."

Karpoš was a new neighborhood built after the earthquake on a large plot of nationalized land. Like other neighborhoods that emerged during this period, Karpoš represented a critical commitment towards social change by firmly shaping domestic space. Once completed, greenery and generous public spaces for collective use dominated the neighborhood. Its design reflected the rigid principles of spatial arrangement of prefabricated building blocks in a fixed structural grid (Fig. 2); a kindergarten, primary and secondary school were also provided within walking distance and access to amenities among residents was predefined, similar to many newly built neighborhoods in CEE (Hess \& Metspalu, 2019).

A one-bedroom apartment in Karpoš was 30.5 square meters in size, a two-bedroom apartment was 47.7 square meters, and a three-bedroom apartment was 67.6 square meters (Fig. 3). Each apartment was outfitted with a balcony, open to the air, providing light and fresh air to the apartment in a city where heatwaves are common during summer months. The balcony could be accessed directly through the living room or the bedroom; 



Fig. 3 Ground floor plan of apartment building in Karpoš with two entrances. Architect: Ilija Karčicki Source: Institute for housing-communal management - Skopje, 1968, used with permission

it consumed the length $(3.2 \mathrm{~m})$ of an entire prefabricated panel and was approximately one meter wide. Although the sizes of the apartments and the rooms were small, the dwellings provided residents with opportunities for individual, efficient and compact living in a newly built neighborhood in Skopje.

\section{Post-1991 Housing and the Legal System Supporting Apartment Expansion in Skopje}

The political, economic and societal processes of change after the fall of socialism and the dissolution of Yugoslavia in 1991 led to radical transformations in the built tissue of Skopje (Stefanovska \& Koželj, 2012). Individual home ownership was central to the privatization processes in Macedonia, in which sitting tenants in state-owned dwellings were given the right to buy apartments they inhabited. Following adoption of privatization laws in Macedonia, approximately $95 \%$ of the dwelling stock was privatized in the 1990s (Bouzarovski et al., 2011).

The housing market in post-1991 Skopje transitioned as well. During this period, there was a significant lack of new housing across the country as construction companies transitioned toward the market economy. There were serious shortages of newly built apartments at affordable prices, and residents lacked sufficient financial resources to relocate to larger housing if they so desired. The buildings that were built in Skopje during state socialism 
were in poor condition and sorely neglected by the early 1990s, resulting from more than four decades of lack of maintenance.

Beginning in 1995 and lasting for 20 years, the residents of Karpoš—through primarily individual initiatives (and lacking coordinated development activities at the central or local level) - retrofitted individual apartments and their architectural, technical and functional components. Roof insulation and pitched roofs were added to deteriorated flat roofs. Other upgrades in individual apartments include kitchen and bathroom renovations and energy efficiency improvements.

The commercialization process since 1991 also contributed to transformations in land use patterns in Karpoš, as some of the apartments were transformed into medical or legal practices and garages turned into shops, bakeries and convenience stores. These changes directly impacted local economies, since housing dominated these neighborhoods during the socialist period.

Parallel to these initiatives, families grew in size the sitting tenants required larger dwelling space. To provide more living space for their families, some tenants enlarged their apartments by expanding or enclosing balconies, thus transforming balconies into interior living space. In fact, a balcony was the first space from which an apartment could possibly be enlarged, and in some cases the enlargement created approximately 15 square meters of additional dwelling space (more than $1 / 3$ the original size of the apartment). While such interventions increased the interior living space, they reduced opportunities for apartment dwellers to commune with nature from within the apartment (Fig. 4). Balcony enclosures also changed proportions of the expanded rooms, almost $9 \mathrm{~m}$ long and $3 \mathrm{~m}$ wide and reduced the amount of natural daylight penetrating from the windows to the depth of the interior.

The modular aspects of the prefabricated housing units enabled expansion of balconies and their transformation into rooms. The original balconies had limited practical use, however they suddenly became useful when apartment owners exploited that space for their individual gain of more comfort and ultimately dwelling space. These individual interventions contributed to changes in the massing proportions of the buildings and building façades (Fig. 5). Often, the enclosure of balconies was not performed with high quality design, materials, or execution. The architect Ilija Karčicki notes that "from a seismic point of view, it is wrong and harmful to expand, upgrade and extend these buildings. It is particularly dangerous to do so, and in the last 20 years it was done in Karpoš without seismic checks" (Interview 2020).

The expansion of balconies in Skopje began as a spontaneous practice and unplanned activity, and the resulting outcomes reflect diverse and non-uniform approaches to neighborhood renovation in post-1991 Skopje. A lack of coordination of individual renovation efforts and the transition to new planning laws and institutions in the early 1990s enabled illegal construction of balcony expansions across the country. Legalization for illegal buildings was enacted in North Macedonia (in 2011) and according to 2013 amendments, illegal dwelling space can be legalized by paying a fee of 1 euro per square meter of built space. The enactment of the law and the minor fees for legalization of illegal building space were supported by politicians who justified it as a benefit to the "loyal citizens of the municipality" according to the Mayor of Karpoš (Petrov, 2013). The 2013 amendments to the law stipulate that $60 \%$ of the funds for legalization are paid to the city of Skopje and $40 \%$ are paid to the municipality ${ }^{1}$ in which the illegal construction is found. In late 2019,

\footnotetext{
1 The city of Skopje consists of 10 municipalities. Within the municipal structure of North Macedonia, Skopje has a special status as a capital city and is also a separate unit of local self-government. The 10 municipalities within Skopje are local self-government units responsible for urban planning and issuing building permits within their boundaries.
} 


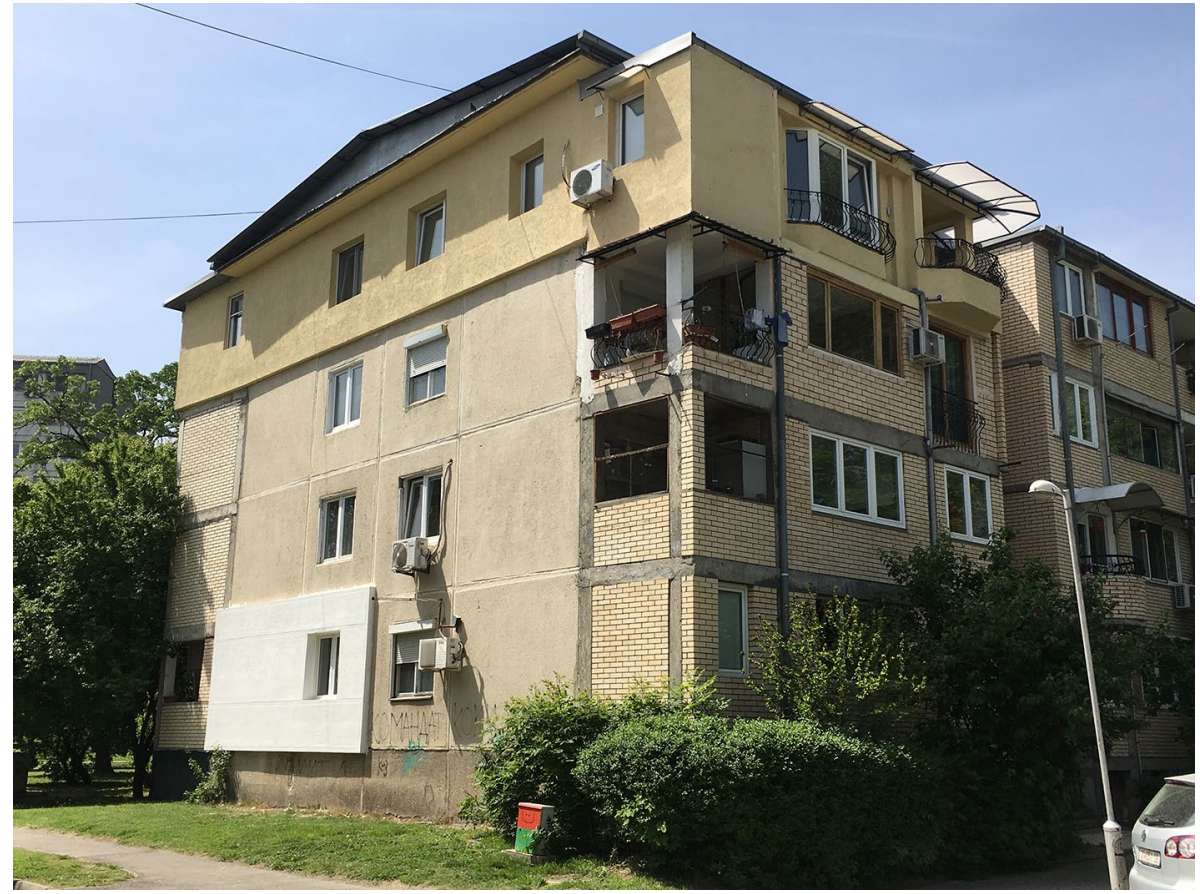

Fig. 4 Individual initiatives guiding the transformation of apartment buildings in Karpoš: a) expanded balconies enclosed into dwelling space and b) thermal performance improvements for individual apartments through extra layers of insulation on the façade, external air-conditioning units, and double-glazed windows. The original prefabricated panels are still visible on the façade Source: Authors' photograph

the government - through the Ministry of Transport and Communications-announced the need for a new law for legalization of illegal construction, proposing an increase to 100 euros per square meter as a penalty. The intention is to stimulate legal construction and discourage illegality. The potential effects of such changes will be known after the law is enacted.

The construction and expansion of balconies is still an ongoing trend making a significant impact on socialist-era buildings (Table 1). Illegal expansions peaked between 2005 and 2006, while the share of construction of illegal balconies was highest between 2006 and 2008. Since then, illegal construction has slowed in Karpoš and in 2018 there was none.

Since the mid 2000s, balcony expansions are subject to legal approval and apartment owners are required to follow municipal planning guidelines, a process that is directly linked to the diminishing numbers of illegal expansions and balcony renovations. At present, the right to issue building permits, including approval of the expansion of balconies, lies with mayors at the municipal level and is subject to review of DUPs (Detailed Urban Plans). ${ }^{2}$

\footnotetext{
2 The DUP is a master plan within the boundaries of a defined neighborhood in a municipality, governing development and building activities and serving as a tool for granting building permits. It is a document based on which specific building conditions for individual building plots are issued, specifying the size, height and the use of individual buildings.
} 


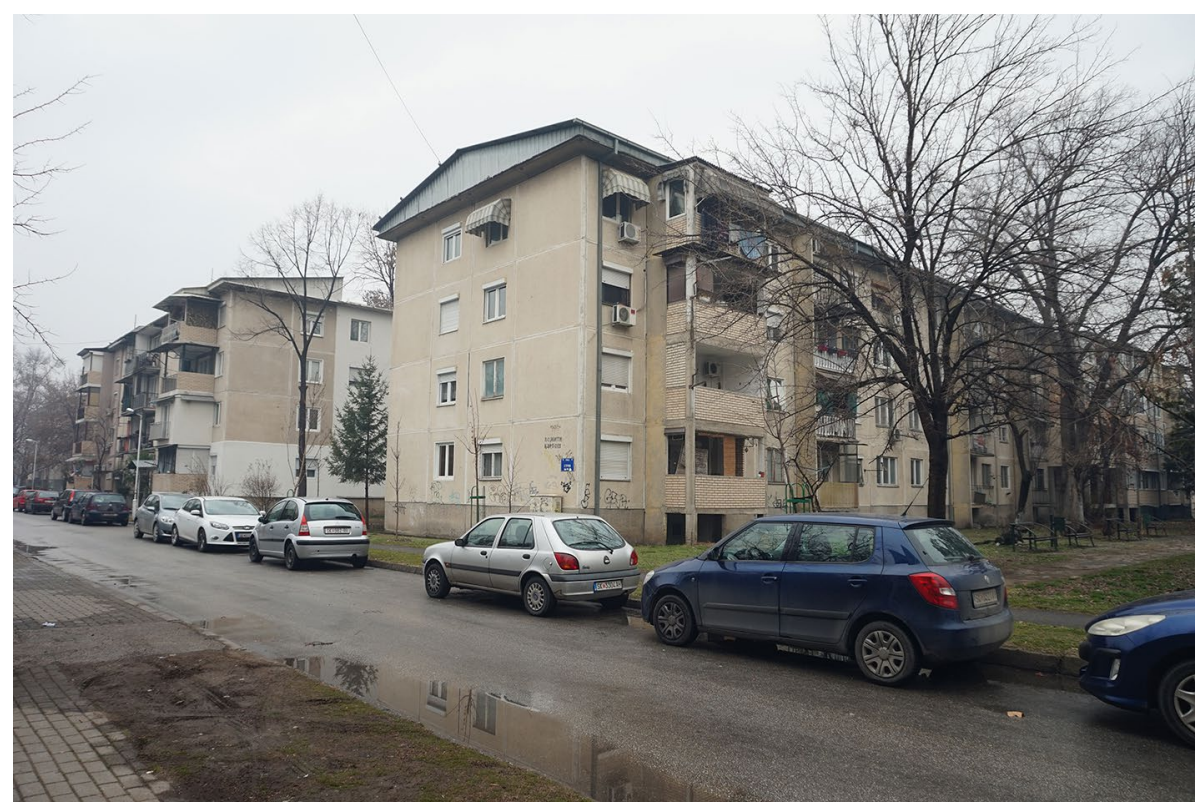

Fig. 5 Changes in massing proportions of prefabricated apartment buildings in Karpoš, where inferior design, poor choice of materials, and display of individuality dominate the townscape Source: Authors' photograph

According to article 63 of the Building Law, apartment building renovations, including expansion of balconies, must follow the same procedure as obtaining a building permit for a new building prescribed in the Building Law. The same law requires that expansion of the surface of existing buildings can occur to the maximum permitted dimensions provided by the DUP; a consent of the majority of apartment owners should be given prior to the commencement of construction or renovation. The first DUP for this area of Skopje was adopted in 2008 and the most recent in 2013. In the two plans-similar in their proposals for neighborhood development - the footprint of the individual buildings built during state socialism is enlarged on both sides, accommodating space for expansion of rooms, balconies and re-defining original balcony dimensions (Fig. 6). The adoption of these two plans follows a lengthy preceding period of planning inactivity, but also recognition of housing renovation and expansion of balconies already underway in apartments in Karpoš.

The expansion of balconies helped to address changing housing preferences of apartment owners in post-1991 Skopje. The transformation of the urban fabric in Karpoš as a result of these processes is individually driven by apartment owners, directly dependent on their financial capabilities. As a result, the egalitarian cityscape 
Table 1 Number of illegal building expansions and balconies in the Republic of North Macedonia, Skopje, and Karpoš municipality

\begin{tabular}{|c|c|c|c|c|c|c|}
\hline & \multicolumn{3}{|c|}{ Illegal Building Expansions } & \multicolumn{3}{|c|}{ Construction of Illegal Balconies } \\
\hline & $\begin{array}{l}\text { Republic of North } \\
\text { Macedonia }\end{array}$ & Skopje & Karpoš & $\begin{array}{l}\text { Republic of North } \\
\text { Macedonia }\end{array}$ & Skopje & Karpoš \\
\hline 2004 & 448 & 130 & $28(21.5 \%)$ & 85 & 62 & $21(33.9 \%)$ \\
\hline 2005 & 549 & 208 & $33(15.9 \%)$ & 156 & 105 & $19(18.1 \%)$ \\
\hline 2006 & 648 & 210 & $47(22.4 \%)$ & 179 & 127 & $35(27.6 \%)$ \\
\hline 2007 & 762 & 336 & $26(7.7 \%)$ & 141 & 93 & $51(54.8 \%)$ \\
\hline 2008 & 640 & 220 & $24(10.9 \%)$ & 166 & 147 & $41(27.9 \%)$ \\
\hline 2009 & 638 & 287 & $33(11.5 \%)$ & 57 & 13 & $5(38.5 \%)$ \\
\hline 2010 & 394 & 147 & $15(10.2 \%)$ & 65 & 21 & $8(38.1 \%)$ \\
\hline 2011 & 304 & 150 & $11(7.3 \%)$ & 37 & 16 & $11(68.8 \%)$ \\
\hline 2012 & 208 & 85 & $14(16.5 \%)$ & 34 & 24 & $20(83.3 \%)$ \\
\hline 2013 & 174 & 63 & $13(20.6 \%)$ & 58 & 43 & $26(60.5 \%)$ \\
\hline 2014 & 176 & 36 & $10(27.8 \%)$ & 45 & 33 & $30(90.9 \%)$ \\
\hline 2015 & 163 & 44 & $5(11.4 \%)$ & 26 & 6 & $1(16.7 \%)$ \\
\hline 2016 & 174 & 36 & $3(8.3 \%)$ & 26 & 11 & $5(45.5 \%)$ \\
\hline 2017 & 122 & 19 & $3(15.8 \%)$ & 15 & 3 & $1(33.3 \%)$ \\
\hline 2018 & 133 & 20 & $2(10.0 \%)$ & 15 & 8 & $0(0 \%)$ \\
\hline
\end{tabular}

State Statistical Office of the Republic of North Macedonia

Note: For comparison in interpreting the share of illegal expansions and balconies in Karpoš, reference data has been provided for Skopje and the Republic of North Macedonia. The share of illegal expansions and balconies in Karpoš is in relation to the relevant totals for Skopje

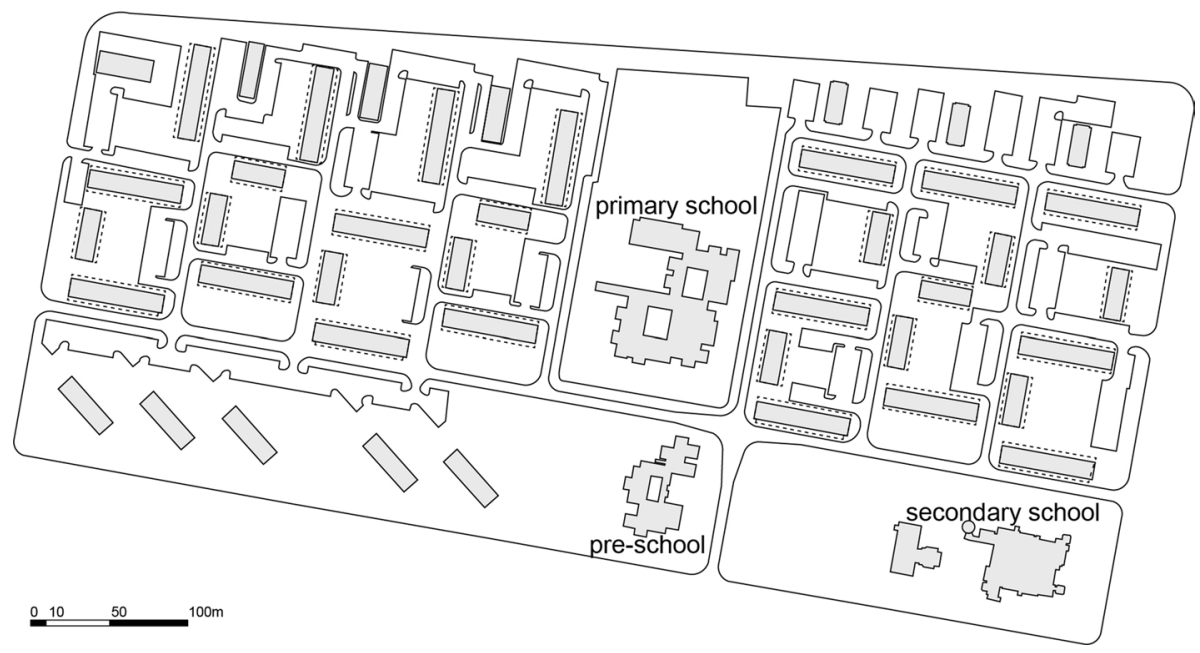

Fig. 6 Plan of Karpoš (late 1960s to early 1970s), Skopje, dominated by prefabricated panel apartment buildings. The dashed line indicates the areas for possible expansions of the footprints of original buildings, based on the 2013 neighborhood master plan Source: Created by authors 

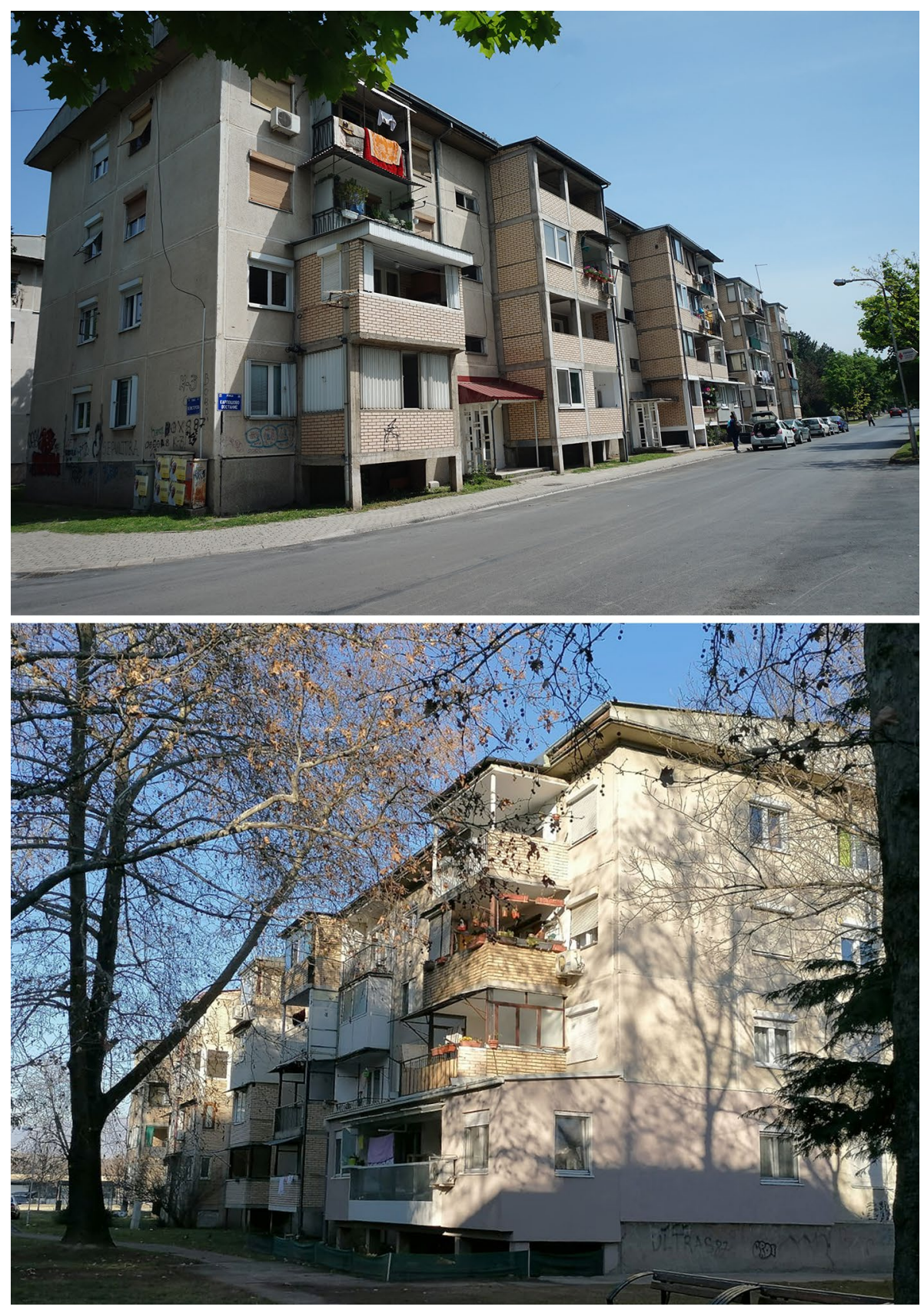

Fig. 7 Expansion of balconies in apartment buildings in Karpoš Source: Authors' photographs

of Karpoš, with its highly uniform apartment buildings connected to centralized socialist planning, is transformed into one where financial means, tastes and preferences are on display, in direct opposition to the aim of the pre-1991 socialist system (Fig. 7). 


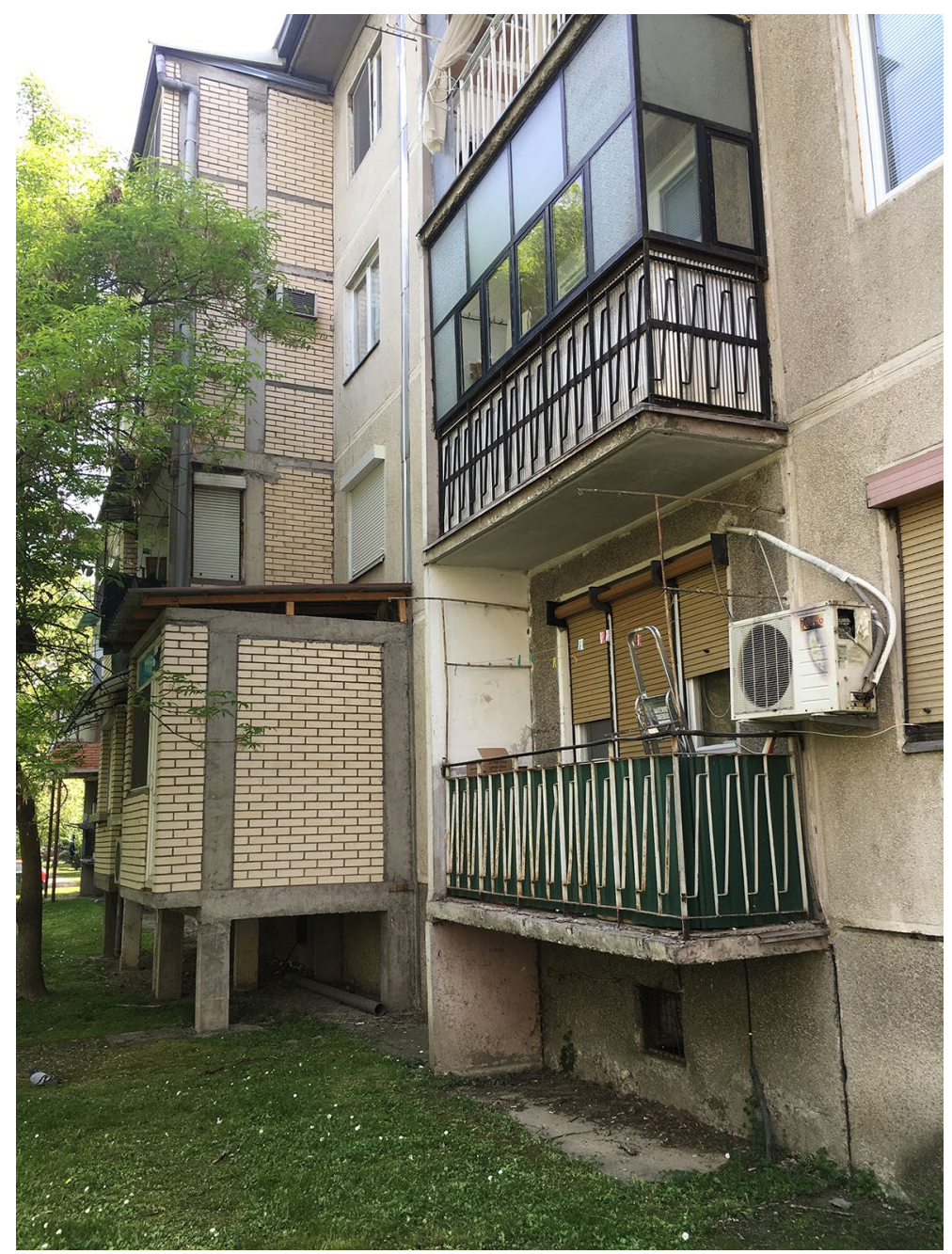

Fig. 8 A view of both original and expanded balconies in apartment buildings in Karpoš Source: Authors' photograph

The transformation of large housing estates in Skopje differs significantly from apartment building renovation in other post-socialist cities that are already part of the EU, where EU funds are earmarked for improving housing estates, which are considered critical challenges for society (Cirman et al., 2013). The lengthy transition of North Macedonia and poor resources has resulted in individual renovations of apartment buildings. An integrated approach in Karpoš, in which the municipality leads and manages the process of its transformation, could be more productive than privately-controlled actions where individual decisions, preferences and opportunities still dominate neighborhood transformations. 


\section{Views from the Neighborhood}

Gradual improvements to housing estates, renovation of individual apartments and enclosure (full or partial) of existing balconies in Skopje since 1991 has been an ongoing process. Through legislation and formalized planning in Karpoš one decade later, these interventions became more organized undertakings. The expansion of balconies has visible impact on the transformation on the built tissue of Karpoš where individual preferences are still the prevailing factor (Fig. 8), also impacting the relocation tendencies of its residents.

In order to understand the decisions underlying the expansion of balconies in greater detail, we organized four focus groups in Karpoš in 2019 and 2020 with local residents and apartment owners who were recruited on site. We were interested in residents' views and reactions to four processes: (a) the expansion of balconies and the legislative processes attached to it; (b) the transformation of their individual apartments following the expansion of balconies; (c) the qualities of the expanded apartments; and (d) their assessment of neighborhood change resulting from these processes.

Discussions taking place during the focus groups suggest that first, residents embraced the idea of having larger living space while remaining in the neighborhood. Second, private developers who emerged in post-socialist Skopje recognized the demand for apartment renovation and approached residents, offering fee-based design and construction of balcony expansion. Third, the expansion of balconies was financed individually by apartment owners, however according to the Building Law a consent of the majority of apartment owners must be acquired. The son of an apartment owner recalls the process:

"In 1995 a developer approached us and took all residents across the neighborhood to see what is happening and what can be done with the expansion of balconies. Then he informed us how much it will cost and after everyone agreed to the project and the proposed price, the developer went to apply for a building permit. It was necessary that we all agreed to expand the balconies."

The role of private developers in the process of expansion of balconies in Karpoš was a prevailing theme during the focus groups. They were important stakeholders in the process who recognized the demand for more living space through expansion of balconies and with guaranteed profit in the process, they approached apartment owners in Karpoš. They also facilitated the process of building permit application, perceived by many residents as an administrative hurdle. An apartment owner who expanded but did not enclose the balcony in their apartment reflected on the role of the developers in the expansion process:

"When the (expanded) balconies began to appear in 1995, the building administrator $^{3}$ approached me and asked if I was interested in expanding the balcony. We had a balcony that was 2.5 square meters and with the expansion we increased to nearly 8 square meters. The developer was responsible for the design and construction... he had been through the same process with other buildings in the neighborhood already. Each apartment owner in the building had to pay individually for the work done in their apartment."

\footnotetext{
${ }^{3}$ Based on the 2009 Housing Law, apartment owners choose an apartment manager to serve for a period of 5 years. Apartment building management can also be performed by a registered professional company employing at least 5 employees. Apartment owners have the right to choose their preferred arrangement for management of apartment buildings.
} 
The focus groups in Karpoš suggest that developers and investors were attracted to the neighborhoods with prefabricated apartment buildings. They were the first to approach the apartment owners and not vice versa, leading to renovation after the majority of the apartment owners (51\%) agreed.

Legislation that legalized the expanded balconies for one euro per square meter of living space was welcomed in the neighborhood. The residents found this process straightforward, did not find it administratively challenging (unlike building permit applications), and individually applied for it. An apartment owner recalls his application for legalization of an expanded balcony:

"I moved here in 2006 from another part of the city. The previous owner had already expanded the balcony, but it was not enclosed at that stage. I legalized the expansion of the balcony - a very straightforward process. We submitted the documents in the municipality, payed one euro per square meter (our expansion is 14 square meters) and now my apartment is 57 square meters. When I moved here, I divided one of the rooms (in a one-bedroom apartment) into two rooms, as the room already had windows on two different facades of the building. The newly added room is very small though."

Another focus group participant expanded the balcony once the masterplan for the neighborhood was adopted and followed the official procedure with application for a building permit prior to expanding:

"I have lived here since 1995, in a two-bedroom apartment in which two of the balconies have been expanded. I am waiting to see what is going to happen with the law for legalization for one euro per square meter, as I am planning to expand my apartment-even in places where there are no balconies-following the outline of the building established in the masterplan."

When asked to identify the most important factors leading to the process of expansion of balconies, the respondents noted that adding more living space to an apartment played the most important role when deciding to expand the balcony. Surprisingly, during the focus groups, respondents did not identify project cost as a deciding factor in the decision to renovate. One respondent noted:

"The expansions of balconies allowed people to get more space, enlarge the interior space, and improve the quality of life in the apartments."

Another person comments:

"In small apartments of around 40 square meters, every possible square meter that could be added counts. In many of the apartments in the neighborhood, there are three generations living in one apartment. More dwelling space and expansion where possible is always welcome."

At the same time as apartments were expanded in size, there were other improvements that residents pointed out improved their daily comfort. In some cases, additional layers of thermal insulation were added to the façades, roofs were rebuilt, single-glazed panes were replaced with double- or triple-glazed windows, and kitchens and bathrooms were renovated. These improvements corrected deficiencies (related to energy efficiency) in the original construction of the apartment buildings and addressed decades of deferred maintenance (Lihtmaa et al., 2018). 
The qualities of the newly acquired or expanded rooms were of little concern to residents. When asked to identify challenges they experience within the interior living space of individual apartments, a participant made the following comment:

"The only problems in the apartment are the plumbing and electricity, so we recently completely upgraded these utilities."

On the thought of relocating to a larger apartment elsewhere in Skopje if a balcony expansion in Karpoš was not possible, one participant stated:

"We never considered relocating to another part of Skopje. Even if we did not expand the balcony, we would still be living here."

A respondent who did indeed relocate to another part of the city commented:

"I lived in Karpoš for 12 years and in 1989 we bought a larger apartment in the city center, so we relocated. That was before expanding the apartment balcony was even possible. I am no longer interested in living in this apartment or in the neighborhood, but I can say that the apartment was a great starting point for young families then, and even now. Years later, my son started his family here like I did before also relocating to the city center."

The ties among residents and apartment owners in socialist apartment buildings are often significant, especially the social interactions among long-term neighbors. Regarding the qualities of the neighborhood, owners unanimously agreed that they were satisfied with the amenities in Karpoš. The proximity to services, public transport and educational institutions, all within comfortable walking distance, contributed to residents' decisions to remain in Karpoš even when there were reasonable opportunities to relocate to other neighborhoods (Hess, 2018). The density of the neighborhood and the green public space are appealing, as one respondent describes:

"We like most the proximity of the neighborhood to the city center, the easily accessible shops and the open space between the buildings. The neighborhood is ideal for living. We would never support any projects that densify the neighborhood, to avoid creating further problems with parking."

Another resident mentioned neighborhood amenities and the planning legislation which has preserved both the building density and the greenspace between buildings (by disallowing the insertion of new buildings):

"This neighborhood is excellent: there is a kindergarten, an elementary school and a high school, all in very close proximity. The greenery is appealing. These basic neighborhood services and comforts are rare now."

Comparison with newly built neighborhoods where the density is higher and there is less green space is certainly an important reason to not relocate from Karpoš. One of the respondents, a newcomer to the neighborhood who rented an apartment that was transformed into an office space (to house a construction company) while living in a neighborhood other than Karpoš reflected on the qualities of Karpoš:

"We have rented a commercial space for one year: a two-bedroom apartment with an expanded balcony that is completely transformed into an office space. The location of the neighborhood is terrific. We were frustrated with parking in our previ- 
ous office location, so we decided to relocate. The most important thing for us is that we are visible from the street and that our clients can readily park nearby."

In Karpoš’ public green space, residents can meet and interact. However, it is also a space where an increased number of cars in the neighborhood is evident. An apartment owner comments:

"Throughout the years, parking became more congested. Large areas of green space are replaced with surface parking and the space for gardens, grass, and trees has noticeably diminished. The streets are sometimes blocked with parked cars as well. Neighborhood infrastructure is poorly maintained."

Another mentions:

"The only problems in the neighborhood arose with the construction in 2012 of City Mall (the largest shopping mall in Skopje, located at the city's western edge). As a result, the parking in the neighborhood is congested on weekends or when there are sales in the shopping mall. Besides our complaints about the shopping mall, living here is excellent. It is very close to the city center, also within walking distance."

\section{Findings}

This study explores the mechanisms related to renovation and expansion of individual apartments through expansion of balconies in apartment buildings constructed with prefabricated panels in post-privatization Skopje. Interviews with residents suggest that the expansion of balconies began around 1995 as an individual activity, while people exploited the planning and regulatory vacuum generated following the disintegration of socialism in the country.

The expansion of balconies contributes positively to dynamics of the city's housing market. In some cases, the possibility to expand balconies can represent a substitute to housing relocation, offering an important alternative to new housing construction in a neighborhood dominated by people in the labor force. This study consequently produces five key findings:

- Apartment owners in Karpoš have expanded balconies to provide more living space prompted by individual living necessities, however these individual actions determined urban planning decisions made at the neighborhood level. The expansion of balconies in prefabricated apartment buildings was a significant economic activity individually financed, and approximately 86 per cent of apartments in the case study neighborhood are enlarged through balcony expansion. These interventions contributed to a lower rate of residential mobility, as highlighted by the interviewed residents. In addition, the expansion of balconies was not seen as a property investment but instead as an improvement of living conditions through expansion of dwelling space. Lacking a unified approach towards regeneration of housing estates in Skopje, the decision to expand balconies was certainly dictated by private financial resources and household incomes.

Changes in the internal organization of apartments were made only after balconies were expanded, creating opportunities to add an extra room to the apartment or enlarge the bedroom or the living room. In a majority of cases, balconies were enclosed follow- 
ing the expansion, resulting in some cases with rearrangement of internal organization of apartments. In cases where balconies were not enclosed but only enlarged, the internal organization of apartments remained the same. The layout and the modular aspect of an apartment play important roles in expansion.

Perceptions of neighborhood residents are generally positive, and residents are satisfied with their living conditions in Karpoš. Focus groups in the neighborhood suggest that the metropolitan location of Karpoš is one of the factors that contributes to the decision to remain in the neighborhood, even if the apartment owners were unable to expand their balconies. Other assets positively impacting the decision to remain include proximity to greenspace, lower population density, and convenient neighborhood services. Improving individual apartments through renovation or expansion and enclosure of balconies contributes even more to the possibility of remaining in the neighborhood without relocating.

Expansions of balconies and improvements in the energy performance of individual apartments are desirable and are viewed as important steps towards improving living conditions in prefabricated apartment buildings in Karpoš. The expansion of balconies contributes directly to increasing the size of individual apartments, in some cases adding up to one third of the original size. The improvement of the energy performance of the apartment contributes to reductions in energy consumption and better regulation of its indoor climate.

Urban planning regulations support the expansion of balconies in Karpoš through the enlargement of building footprints in the Detailed Urban Plans for the neighborhood. We examined the decision to expand balconies in relation to city planning processes after 1991. It is clear that since 2008, planning guidelines at the municipal level support expansion of balconies in existing apartment buildings through enlargement of their original footprints, indicating the maximum area for expansion.

The law for legalization of illegal construction and low fees associated with the process (one euro per square meter of living space) directly impacts individual decisions to expand balconies by bypassing the law. As a result of the low fees for legalization of illegal construction, apartment owners are likely to first expand and later apply for legalization of the expansion. The law on treatment of illegally constructed buildings in North Macedonia is also a political tool, supporting such actions in the country still under transition.

\section{Conclusion: the Transformation of Housing Estates in Skopje Under transition}

The expansion of balconies in Skopje can be seen as a symbol of post-socialist transformation and liberalization of construction activities. It also emphasizes the interests of people in improving their individual housing conditions and adding more dwelling space to their apartments; enlargement of apartment living space through balcony enclosure became a dominant form of transformation of socialist-era housing estates. A lack of masterplans and coordinated planning initiatives after the 1991 disintegration of Yugoslavia-situated within the context of a legal vacuum-contributed to the trend in Skopje to enlarge dwelling units in prefabricated apartment buildings, mostly in illegal ways. The desire of residents to have larger apartments with little (economic) feasibility to relocate elsewhere has been an integral part of the transformation of Karpoš, where management fees and utility 
costs are extremely low and in sharp contrast to districts with newly built apartments. These conditions reflect the reality across former member states of Yugoslavia or countries in a similar phase of EU accession as North Macedonia.

Apartment owners and private developers played a key role in this process, supported by the municipal-level planning process that permitted expanding the footprints of existing buildings in neighborhood masterplans since 2008 and consequent legalization of illegal building expansions. While facades and footprints of existing buildings were changed in the process, these interventions did not greatly affect the public realm of Karpoš. Access to public space still remains an important decision-making factor for people deciding to relocate to and from the neighborhood.

This article contributes to discussions about the post-privatization transformation of housing estates in Skopje through individual decisions and mechanisms that enabled the expansion of balconies through masterplans prepared and adopted at the municipal level and legislation at the national level, critically analyzing the complex relationship between planning and governance after the fall of state socialism in relation to the transformation of housing estates. While the legislation should foster a coordinated approach at the neighborhood scale, our inquiry in Karpoš reveals reactions from individual apartment owners in the process of expansion of balconies. Future planning for such neighborhoods should provide opportunities for expansion, following (a) studies about the seismic properties of existing buildings and (b) coordinated efforts in their materialization, in consultation with apartment owners and various stakeholders (including private developers and municipal planners).

Open Access This article is licensed under a Creative Commons Attribution 4.0 International License, which permits use, sharing, adaptation, distribution and reproduction in any medium or format, as long as you give appropriate credit to the original author(s) and the source, provide a link to the Creative Commons licence, and indicate if changes were made. The images or other third party material in this article are included in the article's Creative Commons licence, unless indicated otherwise in a credit line to the material. If material is not included in the article's Creative Commons licence and your intended use is not permitted by statutory regulation or exceeds the permitted use, you will need to obtain permission directly from the copyright holder. To view a copy of this licence, visit http://creativecommons.org/licenses/by/4.0/.

\section{References}

Andrews, K. D., \& Sendi, R. (2001). Large housing estates in Slovenia: A framework for renewal. International Journal of Housing Policy, 1(2), 233-255. https://doi.org/10.1080/14616710110083443

Blazhan, R. (Director). (2020). Enter through the balcony [Film]. Minimal Movie.

Bouzarovski, S., Salukvadze, J., \& Gentile, M. (2011). A socially resilient Urban transition? The contested landscapes of apartment building extensions in two post-communist Cities. Urban Studies, 48(13), 2689-2714. https://doi.org/10.1177/0042098010385158

Cirman, A., Mandič, S., \& Zorić, J. . (2013). Decisions to renovate: identifying key determinants in central and Eastern European post-socialist Countries. Urban Studies, 50(16), 3378-3393. https://doi.org/10. $1177 / 0042098013482509$

Gorczyca, K. (2016). The social transformation of large housing estates in Poland at the turn of the $21^{\text {st }}$ Century. Czech Sociological Review, 52(6), 861-892.

Hamilton, F. E. I., Dimitrovska Andrews, K., \& Pichler-Milanović, N. (2005). Transformation of cities in Central and Eastern Europe: Towards globalization. United Nations University Press.

Hegedus, J., \& Tosics, I. (1996). The disintegration of the East European housing model. In D. Clapham, J. Hegedus, K. Kintrea, \& I. Tosics, with H. Kay (Eds.) Housing Privatization in Eastern Europe (pp. 15-40). Westport, CT Greenwood Press. 
Hess, D. B. (2018). Transport in Mikrorayons: Accessibility and proximity to centrally planned residential districts during the socialist Era, 1957-1989. Journal of Planning History, 17(3), 184-204. https://doi. org/10.1177/1538513217707082

Hess, D. B., \& Metspalu, P. (2019). Architectural transcendence in soviet-era housing: Evidence from socialist residential districts in Tallinn, Estonia. In D. B. Hess \& T. Tammaru (Eds.), Housing Estates in the Baltic Countries: The Legacy of Central Planning in Estonia, Latvia and Lithuania (pp. 139160). Springer.

Hess, D. B., \& Tammaru, T. (2019a). Modernist Housing Estates in the Baltic Countries: Formation, Current Challenges and Future Prospects. In D. B. Hess \& T. Tammaru (Eds.), Housing Estates in the Baltic Countries: The Legacy of Central Planning in Estonia, Latvia and Lithuania (pp. 3-27). Springer.

Hess, D. B., \& Tammaru, T. (Eds.). (2019b). Housing Estates in the Baltic Countries: The Legacy of Central Planning in Estonia, Latvia, and Lithuania. Springer.

Hess, D. B., Tammaru, T., \& van Ham, M. (Eds.). (2018). Housing Estates in Europe: Poverty, Ethnic Segregation and Policy Challenges. Springer.

Kährik, A., \& Tammaru, T. (2010). Soviet prefabricated panel housing Estates: Areas of continued social mix or decline? The Case of Tallinn. Housing Studies, 25(2), 201-219. https://doi.org/10. 1080/02673030903561818

Kreja, K. (2007). Spatial imprints of urban consumption: large-scale retail development in Warsaw. In $\mathrm{S}$. Tsenkova \& Z Nedović-Budić, (Eds.), The Urban Mosaic of Post-Socialist Europe: Space Institutions and Policy. Heidelberg: Springer.

Krisjane, Z., \& Berzins, M. (2012). Post-socialist Urban tresnds: new patterns and motivations for migration in the suburban areas of Riga. Latvia. Urban Studies, 49(2), 289-306. https://doi.org/10. $1177 / 0042098011402232$

Kulić, V. (2012). Architecture and ideology in Socialist Yugoslavia. In M. Mrduljaš \& V. Kulić (Eds.), Unfinished modernisations: between utopia and pragmatism (pp. 36-63). Zagreb: UHA/CCA.

Kulu, H., \& Billari, F. (2004). Multilevel analysis of internal migration in a transitional Country: The Case of Estonia. Regional Studies, 38, 679-696. https://doi.org/10.1080/003434042000240978

Kuusk, K., \& Kurnitski, J. (2019). State-Subsidized refurbishment of socialist apartment buildings in Estonia. In D. B. Hess \& T. Tammaru (Eds.), Housing Estates in the Baltic Countries: The Legacy of Central Planning in Estonia, Latvia and Lithuania (pp. 339-356). Springer.

Leetmaa, K., \& Hess, D. B. (2019). Incomplete Service Networks in Enduring Socialist Housing Estates: Retrospective Evidence from Local Centres in Estonia. In D. B. Hess \& T. Tammaru (Eds.), Housing Estates in the Baltic Countries: The Legacy of Central Planning in Estonia, Latvia and Lithuania (pp. 273-300). Springer.

Leetmaa, K., \& Tammaru, T. (2007). Suburbanization in countries in transition: Destinations of suburbanizers in the Tallinn metropolitan area. Geografiska Annaler B, 89(2), 127-146. https://doi.org/ 10.1111/j.1468-0467.2007.00244.x

Lihtmaa, L., Hess, D. B., \& Leetmaa, K. (2018). Intersection of the global climate agenda with regional development: Unequal distribution of energy efficiency-based renovation subsidies for apartment buildings. Energy Policy, 119, 327-338. https://doi.org/10.1016/j.enpol.2018.04.013

Mandič, S. (2001). Residential mobility versus 'in-place' adjustments in Slovenia: Viewpoint from a society 'in transition.' Housing Studies, 16, 53-73. https://doi.org/10.1080/02673030020015128

Mariotti, J., \& Koželj, J. (2016). Tracing post-communist urban restructuring: Changing centralities in central and eastern European capitals. Urbani Izziv, 27(1), 113-122.

Metspalu, P., \& Hess, D. B. (2018). Revisiting the role of architects in planning large-scale housing in the USSR: The birth of socialist residential districts in Tallinn, Estonia, 1957-1979. Planning Perspectives, 33(3), 335-361. https://doi.org/10.1080/02665433.2017.1348974

Meuser, P., \& Zadorin, D. (2016). Towards a typology of soviet mass housing: Prefabrication in the USSR 1955-1991. DOM Publishers.

Nae, M., \& Turnock, D. (2011). The new Bucharest: Two decades of restructuring. Cities, 28(2), 206219. https://doi.org/10.1016/j.cities.2010.04.004

Petrov, A. (2013). Legalization for one Euro of the balconies and expansions in Karpoš. https://a1on.mk/ macedonia/petrov-legalizacija-za-edno-evro-na-ba/ Accessed on 6.01.2020.

Petrović, M. (2001). Post-socialist housing policy transformation in Yugoslavia and Belgrade. European Journal of Housing Policy, 1(2), 211-231. https://doi.org/10.1080/14616710110083434

Pojani, D. (2010). Tirana. Cities, 27(6), 483-495. https://doi.org/10.1016/j.cities.2010.02.002

Puur, A., Klesment, M., \& Sakkeus, L. (2019). A turbulent political history and the legacy of state socialism in the Baltic Countries. In D. B. Hess \& T. Tammaru (Eds.), Housing Estates in the Baltic Countries: The Legacy of Central Planning in Estonia, Latvia and Lithuania (pp. 31-49). Springer. 
Salukvadze, J., \& Golubchikov, O. (2016). City as geopolitics: Tbilisi, Georgia - A globalizing metropolis in a turbulent region. Cities, 52, 39-54. https://doi.org/10.1016/j.cities.2015.11.013

Seek, N. H. (1983). Adjusting housing consumption: improve or move. Urban Studies, 20, 455-469. https://doi.org/10.1080/00420988320080811

Stanilov, K. (2007). Housing trends in Central and Eastern European cities during and after the period of transition. In K. Stanilov (Ed.), The post-socialist city: Urban form and space transformation in Central and Eastern Europe after socialism. Netherlands: Dordrech, Springer.

Stefanovska, J., \& Koželj, J. (2012). Urban planning and transitional development issues: The case of Skopje. Macedonia. Urbani Izziv, 23(1), 91-100.

Sykora, L. (1999). Processes of socio-spatial differentiation in post-communist prague. Housing Studies, 14(5), 679-701. https://doi.org/10.1080/02673039982678

Tammaru, T., Kährik, A., Mägi, K., Novak, J., \& Leetmaa, K. (2016). The 'market experiment': Increasing socio-economic segregation in the inherited bi-ethnic context of Tallinn. In T. Tammaru, S. Marcińczak, M. van Ham, \& S. Musterd (Eds.), Socio-economic segregation in European capital cities: East meets West (pp. 333-357). Routledge.

Tipple, G. (2000). Extending themselves: User-initiated transformations of government-built housing in developing countries. University of Liverpool Press.

Tosics, I. (2007). Spatial restructuring in post-socialist Budapest. In S. Tsenkova \& Z. Nedović-Budić, (Eds.), The urban mosaic of post-socialist Europe: Space, institutions and policy. Heidelberg: Springer.

Wainwright, O. (2018, Nov 15). Vanity projects and kamikaze loggias: Tbilisi's architectural disaster. Guardian. https://www.theguardian.com/cities/2018/nov/15/vanity-projects-and-kamikaze-loggiastbilisi-architectural-disaster.

Publisher's Note Springer Nature remains neutral with regard to jurisdictional claims in published maps and institutional affiliations. 